\title{
GENE ACTION and COMBINING ABITIY in LINE $X$ TESTER POPULATION of SAFFLOWER (Carthamus tinctorius L.)
}

\author{
Arzu KOSE \\ Transitional Zone Agricultural Research Institute, Eskisehir, TURKEY \\ Corresponding author: arzukose.tr@gmail.com
}

Received: 22.03.2017

\begin{abstract}
This research, having $F_{1}$ hybrids from 6 female lines and 4 male testers, was conducted in order to design to assess the combining ability, to determine the nature and magnitude of gene action, hybrid vigor for yield and related traits and to detect the appropriate crosses for breeding program in safflower. Parents used in the study were developed at the Transitional Zone Agricultural Research Institute (TZARI). In the first year of this research, lines and testers were crossed in all the possible combinations using line $x$ tester mating design. The hybrid population was evaluated in a replicated field trial in Eskisehir, Turkey. According to the results, the specific combining ability (SCA) effects were determined higher than general combining ability effects (GCA) in terms of traits studied. As a result, low ratios of $\sigma^{2} \mathbf{G C A} / \sigma^{2} \mathrm{SCA},\left(\sigma^{2} \mathrm{D} / \sigma^{2} \mathbf{A}\right)^{1 / 2} \mathrm{implied}$ that nonadditive effects controlled the traits studied. Existing non-additive gene action in the population, the selection in the advanced generations like $F_{4}$ or $F_{5}$ might be effective for improving the high seed and oil yield safflower genotypes
\end{abstract}

Key words: Combining ability, Gene Action, Hybrid vigor, Line $\times$ Tester analysis, Safflower

\section{INTRODUCTION}

Safflower has capable of wide adaptation, high drought resistance and can grow in arid areas (El-Lattief, 2012). Taken into consideration cultivation requests, safflower can be easily cultivated in hard to grow areas than other oil plants (Omidi et al., 2012). Nowadays safflower has been gaining increasing popularity. This situation has accelerated in breeding program aimed to meeting the needs of the producers, consumers, industrial end-users demand.

The development of high yield cultivars is a priority aim in many plant breeding programs. Hybridization followed by selection in transgressive segregation is very useful tool in plant breeding. Choice of parents or crosses is an important factor determining success from recombination breeding for seed or oil yield. Beside of this the breeders need general information about gene action and genetic system controlling the genetic variation of the studied traits in the initial phases of plant breeding program.

Line $\mathrm{x}$ tester analysis developed by Kempthorne in 1957 is one of the breeding strategy for predicting the general combining ability (GCA) of parents and selecting of suitable parents and crosses with high specific combining ability (SCA) also to provide information regarding genetic mechanisms controlling important quantitative traits (Yildirim and Cakir, 1986; Rashid et al., 2007; Aslam et al., 2014). A knowledge of general and specific combining abilities and gene actions help to decide breeding methods to be followed to choose desirable genotypes (Salgotra et al., 2009). Malik et al. (2014) described that general combining ability is attributed to additive type of gene effects, while specific combining ability is attributed to non-additive type of gene actions.

Hybrid vigor is the complex phenomenon depending on the balance of additive, dominance and their interacting traits as well as distribution of genes in parental lines and defined the superiority of the hybrid over the mid-parent and higher parent values as heterosis and heterobeltiosis (Allard, 1960).

Combining ability and hybrid vigor are the most important genetic parameters for breeding improved cultivars. Some researchers have studied the combining abilities and gene actions of safflower hybrid populations by using line $\times$ tester analysis and hybrid vigor for various traits (Patil et al., 1992; Patil and Narkhede, 1996; Harish Babu et al., 2005; Sarode et al., 2008; Singh et al., 2008; Shivani et al., 2011; Sameer Kumar et al., 2012). Whereas genetic parameters of some traits were determined in the literature review, oil yield parameters have not been 
examined enough. Present study was designed to assess the combining ability, to determine the nature and magnitude of gene action, hybrid vigor for yield and related traits and to detect the appropriate crosses for breeding program in a line $\mathrm{x}$ tester crossing design for safflower.

\section{MATERIALS AND METHODS}

The present investigation was carried out at the Transitional Zone Agricultural Research Institute, (39 $45^{\prime \prime} 57^{\prime} \mathrm{N}, 30^{\circ} 24^{\prime \prime} 5^{\prime}$ E) in Eskisehir, Turkey. The soil was a clay loam, slightly alkaline $(\mathrm{pH}=7.1), 1080 \mathrm{~kg} \mathrm{ha}^{-1}$ potassium and $89 \mathrm{~kg} \mathrm{ha}^{-1}$ phosphorus and poor in organic matter $(1.3 \%)$.

Six advanced lines (Eas-278, Esd-15, Ekak-2, Ekak-6, Ekak-7, Emek-20) and four testers (line Es-5-198-2, Dincer, Remzibey, Balci registered varieties) were selected on the basis of agronomic characters such as oil content and seed yield. Especially, well adapted to arid environment condition safflower genotypes; Es-5-198-2, Dincer, Remzibey, Balci were used as testers in this research. The lines and testers which were used as female and male plants were emasculated and pollinated by hand described by Knowles (1958). They were crossed following line $x$ tester mating design to produce the hybrid seeds of 24 crosses in 2015 . The seeds of all the individual crosses were harvested separately. The $F_{1}$ of the line $\mathrm{x}$ tester cross along with the parental varieties were grown in randomized block design with four replications in 2016. Each genotype was sown in plots with 4 rows; plots were $2 \mathrm{~m}$ long, with $45 \mathrm{~cm}$ between rows and $25 \mathrm{~cm}$ between plants within rows. At seeding, $80 \mathrm{~kg} \mathrm{ha}^{-1}$ nitrogen (33\% ammonium nitrate) and $60 \mathrm{~kg} \mathrm{ha}^{-1}$ phosphorus (superphosphate) were applied. During growing season weeds were controlled by hand.

Randomly selected ten plants per plot were used to determine yield traits. The followed data was measured number of branch per plant, number of head per plant, head diameter, 1000 seed weight, seed yield of per plant, oil content, oil yield per plant. Plants were harvested in August. Oil content of each genotype was determined by using Soxhlet apparatus. Oil yield of per plant was calculated by multiplying oil content and the seed yield of per plant.

In this study, data were analyzed with the program Tarpopgen PC Program (Ozcan and Acikgoz, 1999). The general combining ability (GCA) variance effects of the parents and the specific combining ability (SCA) variance effects of the hybrids were determined by the using of the line $\mathrm{x}$ tester mating design described by Kempthorne (1957). Hybrid vigor in $F_{1}$ hybrids were computed in relation to the mid-parent and higher parent values (Fonseca and Patterson, 1968). Heterotic effects were tested by the least significant differences (LSD) test at the 0.05 and 0.01 levels. The significance of GCA and SCA effects was determined at the 0.05 and 0.01 levels using the t-test.

\section{RESULTS AND DISCUSSION}

The results of the analysis of variance for line-tester population were presented in Table 1. All genotypes showed differences with respect to the traits studied in this study. This situation indicated that there was a significant variation among lines, testers and hybrids; therefore, it is possible that to compute the general and specific combining abilities in the population parent and hybrids, respectively. The lines used in the research exhibited a variation in terms of number of head per plant, thousands of seed weight, oil content, oil yield while the testers showed significant differences for head diameter and oil content. Also, the interaction between lines and testers were stated as significant for all traits. The variance due to parents vs crosses was also significant for all the characters indicating presence of hybrid vigor for these characters.

Table 1. Mean squares and $\mathrm{F}$ values for line, tester involving parents of the investigated traits

\begin{tabular}{|c|c|c|c|c|c|c|c|c|c|}
\hline Source of variation & & DF & NBP & NHP & TSW & HD & OC & SYP & OYP \\
\hline \multirow{2}{*}{ Replication } & MS & 3 & $16.83 * *$ & $546.60 * *$ & 5.01 & 0.02 & 2.59 & 7.22 & 0.80 \\
\hline & $\mathrm{F}$ & & 4.412 & 17.024 & 0.535 & 1.478 & 2.025 & 0.249 & 0.251 \\
\hline \multirow{2}{*}{ Genotypes } & MS & 33 & $30.17 * *$ & $243.93 * *$ & $64.60 * *$ & $0.26 * *$ & $75.72 * *$ & $174.51 * *$ & $32.48 * *$ \\
\hline & $\mathrm{F}$ & & 7.909 & 7.597 & 6.892 & 14.608 & 59.285 & 6.027 & 10.105 \\
\hline \multirow{2}{*}{ Parents } & MS & 9 & $50.48 * *$ & $425.41 * *$ & $83.82 * *$ & $0.17 * *$ & $148.46 * *$ & $179.52 * *$ & $63.44 * *$ \\
\hline & $\mathrm{F}$ & & 13.233 & 13.250 & 8.942 & 9.456 & 116.243 & 6.200 & 19.732 \\
\hline \multirow{2}{*}{ Hybrids } & MS & 23 & $22.94 * *$ & $167.05 * *$ & $49.46 * *$ & $0.24 * *$ & $49.54 * *$ & $170.49 * *$ & $20.64 * *$ \\
\hline & $\mathrm{F}$ & & 6.015 & 5.203 & 5.277 & 13.809 & 38.785 & 5.888 & 6.423 \\
\hline \multirow{2}{*}{ Parents vs Hybrids } & MS & 1 & $13.61 *$ & $378.80 * *$ & $239.71 * *$ & $1.43 * *$ & $23.19 * *$ & $221.54 * *$ & $26.25 * *$ \\
\hline & $\mathrm{F}$ & & 3.569 & 11.798 & 25.572 & 79.363 & 18.155 & 7.651 & 8.166 \\
\hline \multirow{2}{*}{ Lines } & MS & 3 & 34.98 & $317.01 *$ & $120.12 *$ & 0.39 & $102.49 * *$ & 264.34 & $42.91 *$ \\
\hline & $\mathrm{F}$ & & 2.33 & 3.048 & 3.642 & 1.714 & 12.206 & 1.994 & 3.088 \\
\hline \multirow{2}{*}{ Testers } & MS & 5 & 42.72 & 232.38 & 14.14 & $0.11 *$ & $166.97 * *$ & 203.87 & 17.31 \\
\hline & $\mathrm{F}$ & & 2.853 & 2.235 & 0.429 & 0.495 & 19.884 & 1.538 & 1.246 \\
\hline \multirow{2}{*}{ Lines $\mathrm{x}$ testers } & MS & 15 & $14.97 * *$ & $103.99 * *$ & $32.98 * *$ & $0.22 * *$ & $8.39 * *$ & $132.54 * *$ & $13.89 * *$ \\
\hline & $\mathrm{F}$ & & 3.926 & 3.239 & 3.518 & 12.675 & 6.575 & 4.577 & 4.322 \\
\hline Error & & 99 & 3.81 & 32.10 & 9.37 & 0.01 & 1.27 & 28.95 & 3.22 \\
\hline
\end{tabular}

DF: degree of freedom, MS: mean square, F: F value, NBP: number of branch per plant, NHP: number of head per plant, TSW: thou sands of seed weight, HD: head diameter. OC: oil content. SYP: seed yield per plant. OYP: oil yield per plant. * and $* *$ : significant at $\mathrm{P} \leq 0.05$ and $\mathrm{P} \leq 0.01$, respectively 
The variance due to general combining ability $\left(\sigma^{2} \sigma \sigma\right.$ $\sigma$ ) and specific combining ability ( $\left.\sigma^{2} \mathrm{SCA}\right)$, ratio of GCA : SCA variances, additive variance $\left(\sigma^{2} \mathrm{~A}\right)$, non-additive variance $\left(\sigma^{2} \mathrm{D}\right)$ and degree of dominance $\left[\sigma^{2} \mathrm{D} / \sigma^{2} \mathrm{~A}\right] 1 / 2$ for the traits in study for safflower genotypes were shown in Table 2. The variance due to SCA was greater than the variance due to GCA in terms of all traits studied in this research. It is clear that non-additive gene effects were dominant and control these characters genetically. In contrast to this result, Sing et al. (2008) observed that SCA effects were generally lower than GCA effects for number of branch per plant, number of head per plant, thousands of seed weight and head diameter. Golkar et al. (2012) showed that the number of head per plant was largely governed by dominance gene effects, whereas 1000-seed weight controlled by additive type of gene action. Pankaj (2015) indicated that the additive gene action was the major influence on number of head per plant, thousands of seed weight and seed yield per plant in safflower. The difference in the results may be attributed to differences of parental materials used hybridization and to genotype $\mathrm{x}$ environments. Shivani et al. (2011) used four safflower lines and six testers and tested $24 \mathrm{~F}_{1}$ combinations in a line $\mathrm{x}$ tester. They revealed that variance due to SCA had higher magnitude than GCA variance for all the traits studied indicating that these traits are under the influence of non-additive gene action. Likewise, some genetic studies on gene action in safflower exhibited the importance of non-additive gene action for yield, yield traits and oil content (Patil et al., 1992; Parameshwarappa et al., 1995; Ghorpade and Wandhare, 2001; Gadekar and Jambhale, 2003; Nai et al., 2014; Pankaj, 2015). Singh et al. (1992) suggested that when non-additive gene action is predominant in selfpollinated plants selection should be postponed to later generations.

Table 2. Genetic component estimations

\begin{tabular}{lccccccc}
\hline & NBP & NHP & TSW & HD & OC & SYP & OYP \\
\hline$\sigma^{2} \mathrm{GCA}$ & 0.15 & 1.19 & 0.31 & 0.001 & 0.778 & 0.72 & 0.13 \\
$\sigma^{2} \mathrm{SCA}$ & 2.79 & 17.97 & 5.90 & 0.053 & 1.780 & 25.90 & 2.67 \\
$\sigma^{2}(\mathrm{GCA}) / \sigma^{2}(\mathrm{SCA})$ & 0.05 & 0.06 & 0.05 & 0.018 & 0.437 & 0.028 & 0.05 \\
$\sigma^{2} \mathrm{~A}$ & 0.60 & 4.77 & 1.25 & 0.002 & 3.112 & 2.87 & 0.51 \\
$\sigma^{2} \mathrm{D}$ & 2.79 & 17.97 & 5.90 & 0.053 & 1.780 & 25.90 & 2.67 \\
$\left(\sigma^{2} \mathrm{D} / \sigma^{2} \mathrm{~A}\right)^{1 / 2}$ & 2.15 & 1.94 & 2.17 & 5.14 & 1.322 & 3.00 & 2.28 \\
\hline
\end{tabular}

The proportional contributions of lines and testers and their interactions to the total variance for studied traits were presented in Table 3. The contributions of the lines were found higher than testers for all traits. Line $\mathrm{x}$ tester interaction contributed to combinations' variances was found higher than lines for the investigated traits expect number of head per plant, thousands of seed weigh, oil content and oil yield. According to the result, maximum contributions to the total variance provided by the lines and line $\mathrm{x}$ tester interactions for number of branch per plant, head diameter and seed yield.

Table 3. Proportional contributions of lines and testers and their interaction variances for the investigated traits

\begin{tabular}{ccccrrrrr}
\hline Source of variation & DF & NBP & NHP & TSW & HD & OC & SYP & OYP \\
\hline & & & Contributions (\%) & & & \\
\hline Lines & 3 & 33.14 & 41.25 & 52.79 & 34.21 & 44.97 & 33.70 & 45.18 \\
Testers & 5 & 24.28 & 18.14 & 3.72 & 5.92 & 43.97 & 15.60 & 10.94 \\
Lines x testers & 15 & 42.57 & 40.60 & 43.48 & 59.86 & 11.06 & 50.76 & 43.89 \\
\hline
\end{tabular}

General combining ability (GCA) was defined the average performance of line, tester by Sprague and Tatum (1942). In this study, GCA effects of the lines and testers used in this research were shown in Table 4.

Among the parents the highest positive GCA effect were exhibited by the lines Emek-20 and tester Remzibey in terms of number of branch per plant. Concerning number of head per plant, lines Emek-20, Ekak-7 and testers Es-5-198-2, Balc1, observed exhibited positively significant GCA effects. Regarding thousands of seed weight, among the lines, the genotype Ekak- 6 had highest GCA effects followed by Ekak-7 and Ekak-2 while the testers Dincer was the best general combiner. With respect to thousands of seed weight significant and positive GCA effects were recorded for lines Ekak-6 and Eas-278, tester
Es-5-198-2 for head diameter trait. Among the lines and testers whereas Esd-15, Eas-278, Emek-20 and Balci had significant and positive GCA effects, Ekak-7 Ekak-6 Ekak-2 and Dincer had negative GCA effects for oil content, respectively. For seed yield among the lines and testers significant and positive GCA effects were determined to Eas-278, Ekak-2 and Dincer, respectively. On the other hand, line Eas-278 and tester Balc1 had significant and positive GCA effects in terms of oil yield among the parents. It was obvious that lines and testers indicated variable response having positive GCA for some traits and negative for others. Among the lines Eas-278, Ekak-2 and the tester Balci had positive GCA effects majority of studied traits. Griffing (1956) reported that high GCA effects are result of the additive gene effects or additive-additive interaction effects. Therefore, these 
parents should be considered as the best lines and tester in safflower. breeding program aimed to improve seed and oil yield of

Table 4. General combining ability effects (GCA) of the parents for the investigated traits

\begin{tabular}{lccccccc}
\hline Source of variation & NBP & NHP & TSW & HD & OC & SYP & OYP \\
\hline \multicolumn{1}{c}{ Lines } & & & & & & \\
\hline Eas-278 & 0.09 & -2.47 & $-4.78^{* *}$ & $0.12^{* *}$ & $1.80^{* *}$ & $5.46^{* *}$ & $2.49^{* *}$ \\
Esd-15 & 0.58 & 0.69 & -0.55 & $-0.21^{* *}$ & $3.23^{* *}$ & $-3.02^{*}$ & 0.28 \\
Ekak-2 & 0.61 & 0.78 & $1.77^{*}$ & 0.05 & $-1.82^{* *}$ & $4.25^{* *}$ & 0.51 \\
Ekak-6 & $-1.94^{* *}$ & $-7.41^{* *}$ & $2.55^{* *}$ & $0.16^{* *}$ & $-2.15^{* *}$ & 0.08 & -0.78 \\
Ekak-7 & $-1.42^{* *}$ & $3.32^{*}$ & $1.96^{*}$ & 0.05 & $-2.75^{* *}$ & $-4.55^{* *}$ & $-2.50^{* *}$ \\
Emek-20 & $2.10^{* *}$ & $5.08^{* *}$ & -0.95 & $-0.17^{* *}$ & $1.69^{* *}$ & -2.22 & -0.01 \\
\hline \multicolumn{2}{r}{ Testers } & & & & & & \\
\hline Dincer & $-1.96^{* *}$ & $-3.26^{* *}$ & $1.28^{*}$ & $0.07 * *$ & $-2.78^{* *}$ & $3.62^{* *}$ & -0.09 \\
Remzibey & 0.32 & -2.06 & 0.41 & -0.04 & -0.07 & $-3.17 * *$ & $-1.03^{*}$ \\
Balci & $0.98^{*}$ & $2.62^{*}$ & -1.02 & $-0.08^{* *}$ & $3.56^{* *}$ & -1.27 & $1.04^{*}$ \\
Es-5-198-2 & 0.67 & $2.70^{*}$ & -0.12 & -0.04 & -0.70 & 0.82 & 0.08 \\
\hline SH(for lines) & 0.488 & 1.417 & 0.765 & 0.034 & 0.283 & 1.345 & 0.634 \\
\hline SH(for testers) & 0.399 & 1.157 & 0.625 & 0.027 & 0.231 & 1.098 & 0.518 \\
\hline
\end{tabular}

Specific combining ability effects is an important parameter for estimating and selecting superior cross combinations and measure of non-additive gene action which might be exploited through heterosis generally suggested for cross pollinated species such as maize, sunflower and rye (Ortis et al., 2005; Huang et al., 2013; Dehghanpour and Ehdaie, 2013; Goncharenko et al., 2013; Chigeza et al., 2014; Patel and Shrivastava, 2016). Beside of this specific combining ability effects can be used to select homozygous lines that show transgressive segregation for self-pollinated plants like chickpea, rice, alfa alfa, safflower, wheat (Bicer, 2008; Shukla and Pandey, 2008; Al Lawati et al., 2010; Golkar et al., 2011; Istipliler et al., 2015). In this research data on specific combining ability effects of 24 experimental hybrids for all the traits were illustrated in Table 5 .

It was observed that Emek-20 x Dincer, Ekak-6 x Es5-198-2, Eas-278 x10 Balci, Esd-15 x Remzibey and Ekak-7 x Es-5-198-2 combinations had positive and significant SCA effects for number of head per plant. Positive and significant SCA effect for number of head per plant was observed only in the combination of Ekak-6 x Es-5-198-2. While crosses Ekak-6 x Es-5-198-2 and Ekak-7 x Es-5-198-2 exhibited significant SCA effects for 1000 seed weight, Ekak-6 x Remzibey, Ekak-2 x Remzibey, Esd-15 x Dincer and Eas-278 x Es-5-198-2 had significant SCA effects in terms of head diameter. While most of the hybrid combination had positive SCA effect for seed and oil yield, the significant effect was determined in Emek-20 x Balci (11.54 and 3.91) and Eas$278 \times$ Es-5-198-2 (5.67 and 1.79) crosses involved with the parents having good $\mathrm{x}$ good, good $\mathrm{x}$ poor and poor $\mathrm{x}$ poor general combining ability effects. The involvement of at least one parent with high general combining ability effects and other parents with good or medium or poor general combining ability effects was also reported in several crosses by Sing et al. (2008) and Shivani et al. (2011), Pandya and Patil (1994) emphasize that there was close relationship between hybrid vigor and SCA effects, defining that selection of the crosses based on heterotic response is as effective as selection based on SCA.

Heterosis and heterobeltiosis values are important genetic parameters both positive and negative values are useful and depending on the objective of plant breeding programs. Nowadays, safflower breeding program was aimed to improve seed and oil yield generally, therefore to obtain positive hybrid vigor for these characters is too significant. Heterotic estimates of the cross combinations for seed and oil yield were presented in Table 6 . The highest heterosis and heterobeltiosis were recorded in Emek-20 x Balci (54.3\% and 53.6\%; 49.7\% and 40.1\%) followed by Ekak-6 x Balci (44.8\% and 46.2\%; 36.0\% and $21.8 \%$ ), Eas-278 x Balci $(35.2 \%$ and $36.8 \% ; 22.8 \%$ and $17.5 \%$ ), Eas-278 x Es-5-198-2 (32.8\% and 25.8\%; $24.6 \%$ and $22.6 \%$ ) Ekak-2 x Es-5-198-2 (28.4\% and $25.1 \% ; 16.2 \%$ and $17.8 \%$ ) for seed and oil yield, respectively. In this study, similar heterotic effect was determined between seed and oil yield. Some researcher revealed that seed yield had highest relation with oil yield (Behnam et al., 2011; Naserirad et al., 2013). The highest heterosis was manifested $17.20 \%, 23.41 \%$ and $54.13 \%$ for seed yield by Deshmukh et al. (1991), Singh et al. (2001) and Patil et al. (2004), respectively. Similarly, Sarode et al. (2008) reported that the maximum significant positive relative heterosis value in crosses of safflower $27.2 \%$ for the seed yield. 
Table 5. Specific combining ability effects (SCA) of the crosses for the investigated traits

\begin{tabular}{|c|c|c|c|c|c|c|c|}
\hline Hybrid combination & NBP & NHP & TSW & HD & OC & SYP & OYP \\
\hline Eas-278 x Es-5-198-2 & -0.51 & -3.18 & $-5.67 * *$ & $0.21 * *$ & -0.41 & $5.67 *$ & $1.79 *$ \\
\hline Eas-278 x Dincer & -0.91 & 2.89 & $3.25^{*}$ & -0.04 & 0.60 & 0.50 & 0.49 \\
\hline Eas-278 x Remzibey & -1.05 & -4.02 & 1.14 & -0.09 & $-1.27 *$ & $-7.19 * *$ & $-2.94 * *$ \\
\hline Eas-278 x Balci & $2.46^{*}$ & 4.31 & 1.27 & -0.07 & $1.08 *$ & 1.01 & 0.78 \\
\hline Esd-15x Es-5-198-2 & -0.85 & 1.83 & 0.88 & 0.07 & $1.05 *$ & 0.49 & 0.85 \\
\hline Esd-15x Dincer & -1.85 & 0.14 & 1.22 & $0.28 * *$ & 0.15 & -1.16 & -0.50 \\
\hline Esd-15 x Remzibey & $2.32 *$ & -2.10 & -0.56 & $-0.58 * *$ & $-1.64 *$ & 4.99 & 1.06 \\
\hline Esd-15 x Balci & 0.39 & 0.13 & -1.54 & $0.23 * *$ & 0.43 & -4.32 & -1.41 \\
\hline Ekak-2 x Es-5-198-2 & -1.10 & -1.04 & -1.14 & -0.13 & $-1.48 *$ & 3.15 & 0.09 \\
\hline Ekak-2 xDincer & 1.04 & 2.81 & -2.59 & -0.08 & -0.24 & 3.66 & 1.11 \\
\hline Ekak-2 x Remzibey & 1.94 & 0.10 & 2.01 & $0.31 * *$ & $1.26^{*}$ & -0.93 & 0.41 \\
\hline Ekak-2 x Balci & -1.88 & -1.88 & 1.72 & -0.11 & 0.47 & $-5.89 *$ & -1.62 \\
\hline Ekak-6 x Es-5-198-2 & $2.50 *$ & $8.36 * *$ & $4.47 * *$ & -0.05 & -0.35 & -3.23 & -1.08 \\
\hline Ekak-6 x Dincer & -0.12 & -1.72 & -2.23 & -0.07 & -0.18 & -1.86 & -0.60 \\
\hline Ekak-6 x Remzibey & -1.81 & -2.68 & -0.53 & $0.32 * *$ & $1.79 * *$ & 3.23 & $1.83^{*}$ \\
\hline Ekak-6 x Balci & -0.57 & -3.98 & -1.72 & $-0.20 * *$ & $-1.26 *$ & 1.86 & -0.14 \\
\hline Ekak-7 x Es-5-198-2 & $1.97 *$ & 2.40 & $3.56^{*}$ & -0.13 & -1.00 & 4.28 & 0.87 \\
\hline Ekak-7 x Dincer & -1.07 & $-8.97 * *$ & -2.08 & -0.01 & $1.84 * *$ & 0.38 & 0.85 \\
\hline Ekak-7 x Remzibey & -0.85 & 4.96 & -1.34 & 0.08 & 0.10 & -0.45 & -0.22 \\
\hline Ekak-7 x Balci & -0.05 & 1.61 & -0.14 & 0.06 & -0.94 & -4.20 & -1.50 \\
\hline Emek-20 x Es-5-198-2 & $-2.02 *$ & $-8.37 * *$ & -2.11 & 0.03 & $2.21 * *$ & $-10.37 * *$ & $-2.40 * *$ \\
\hline Emek-20 x Dincer & $2.92 * *$ & 4.84 & 2.42 & -0.08 & $-2.18 * *$ & -1.52 & -1.35 \\
\hline Emek-20 x Remzibey & -0.56 & 3.73 & -0.72 & -0.05 & -0.24 & 0.35 & -0.14 \\
\hline Emek-20 x Balci & -0.35 & -0.20 & 0.41 & 0.01 & 0.21 & $11.54 * *$ & $3.90 * *$ \\
\hline $\mathrm{SH}$ & 0.977 & 2.833 & 1.513 & 0.067 & 0.565 & 2.691 & 0.897 \\
\hline
\end{tabular}

* and **: significant at $\mathrm{P} \leq 0.05$ and $\mathrm{P} \leq 0.01$, respectively

Table 6. Heterosis and heterobetiosis value of hybrids for seed and oil yield

\begin{tabular}{|c|c|c|c|c|}
\hline & \multicolumn{2}{|c|}{ SYP } & \multicolumn{2}{|c|}{ OYP } \\
\hline Hybrids & Ht. & Hb. & Ht. & $\mathrm{Hb}$. \\
\hline Eas-278 x Es-5-198-2 & $32.8 * *$ & $24.6 * *$ & $25.8 *$ & $22.6^{*}$ \\
\hline Eas-278 x Dincer & 5.6 & 0.5 & 5.3 & 3.3 \\
\hline Eas-278 x Remzibey & -15.4 & -24.5 & -18.6 & $-30.3 * *$ \\
\hline Eas-278 x Balci & $35.2 * *$ & $22.8 * *$ & $36.8 * *$ & $17.5^{*}$ \\
\hline Esd-15x Es-5-198-2 & -1.1 & -6.3 & 0.3 & -5.0 \\
\hline Esd-15x Dincer & $-20.0^{*}$ & $-23.2 *$ & -20.0 & $-20.8^{*}$ \\
\hline Esd-15 x Remzibey & -7.8 & -17.0 & -10.2 & $-21.1^{* *}$ \\
\hline Esd-15 x Balci & -5.1 & -14.5 & -3.6 & $-19.2 *$ \\
\hline Ekak-2 x Es-5-198-2 & $28.4 * *$ & $16.2 * *$ & $25.1 *$ & $17.8 *$ \\
\hline Ekak-2 xDincer & 14.6 & 5.1 & 18.8 & -6.1 \\
\hline Ekak-2 x Remzibey & -0.6 & -14.3 & $53.7 * *$ & $-23.2 * *$ \\
\hline Ekak-2 x Balci & 17.0 & 10.3 & $30.2 *$ & $19.9 *$ \\
\hline Ekak-6 x Es-5-198-2 & 13.3 & -7.7 & 11.3 & -16.4 \\
\hline Ekak-6 x Dincer & 0.0 & -17.6 & 0.2 & $-26.9 * *$ \\
\hline Ekak-6 x Remzibey & 9.7 & -14.3 & 15.5 & $-22.5 * *$ \\
\hline Ekak-6 x Balci & $44.8 * *$ & $36.0 * *$ & $46.2 * *$ & $21.8 *$ \\
\hline Ekak-7 x Es-5-198-2 & 15.7 & -1.2 & 9.9 & -14.6 \\
\hline Ekak-7 x Dincer & -15.6 & -27.0 & -5.3 & $-28.7 * *$ \\
\hline Ekak-7 x Remzibey & -15.7 & -31.1 & -15.6 & $-42.0 * *$ \\
\hline Ekak-7 x Balci & 2.8 & 2.2 & 4.9 & -9.1 \\
\hline Emek-20 x Es-5-198-2 & $-19.6^{*}$ & $-29.1 *$ & -17.1 & $-20.5^{*}$ \\
\hline Emek-20 x Dincer & $-12.8 * *$ & -22.2 & -20.2 & $-26.7 * *$ \\
\hline Emek-20 x Remzibey & $-10.6^{* *}$ & $-24.8 * *$ & -12.1 & $-28.7 * *$ \\
\hline Emek-20 x Balci & $54.3 * *$ & 49.7 & $53.6^{* *}$ & $40.1 * *$ \\
\hline
\end{tabular}


A study conducted on Shivani et al. (2011) using line $x$ tester mating design in safflower reported that significant positive heterobeltiosis for seed yield ranged from $10.28 \%$ to $43.58 \%$ and high degree of heterosis $(157.9 \%$ and $171.0 \%$ ) for seed yield was recorded previously by Narkhede and Patil (1987) and Sing et al. (2008). The difference in the results of different researchers studied in the present breeding material can be attributed to the divergence of the material used in studies.

\section{CONCLUSIONS}

Selection for lines and testers with high GCA effects and crosses with high SCA effects would be a suitable strategy for seed and oil yield improvement in safflower. Particularly, the crosses Emek-20 x Balci and Eas-278 x Es-5-198-2 were identified as best combinations for high seed and oil yield due to their higher SCA values. Existing non-additive gene action in the population, it was decided that to obtain superior plants in this hybrid population selection should be delayed following generation such as $\mathrm{F}_{4}$ or $\mathrm{F}_{5}$.

\section{LITERATURE CITED}

Allard, R. W. 1960. Principles of Plant Breeding. John Willey and Sons, New York, London.

Al Lawati, A. H., C. A. Pierce, L. W. Murray and I. M. Ray. 2010. Combining ability and heterosis for forage yield among elite alfalfa core collection accessions with different fall dormancy responses. Crop Sci. 50: 150-158.

Aslam, R., M. Munawar and A. Salam. 2014. Genetic architecture of yield components accessed through Line $\mathrm{x}$ Tester analysis in wheat (Triticum aestivum L.) Universal J. of Plant Sci. 2: 93-96.

Behnam, T., A. Said, S. Mohamadreza, B. B. Alireza and G. Gafari. 2011. Path analysis of seed and oil yield in safflower (Carthamus tinctorius L.). Int. J. Agri. \& Crop Sci. 3: 114122.

Bicer, B. T. and D. Sakar. 2008. Heritability and gene effects for yield and yield components in chickpea. Hereditas 145: 220224.

Chigeza, G., K. Mashingaidze and P. Shanahan. 2014. Advanced cycle pedigree breeding in sunflower. II: combining ability for oil yield and its components. Euphytica 195: 183-195.

Dehghanpour, Z. and B. Ehdaie. 2013. Stability of general and specific combining ability effects for grain yield in elite Iranian maize inbred lines. J. of Crop Improv. 27: 137-152.

Deshmukh, M. P., B. R. Patil and P. B. Ghorpade. 1991. General evaluation of some selected lines of safflower (Carthamus tinctorius L.). Indian J. Agril. Res. 25: 181-188.

El-Lattief, E. A. 2012. Evaluation of 25 safflower genotypes for seed and oil yields under arid environment in upper Egypt. Asian J. of Crop Sci. 4: 72-79.

Fonseca, S. and F. L. Patterson. 1968. Hybrid vigor in a seven parent diallel crosses in common wheat (Triticum aestivum L.). Crop Sci. 8: 85-88.

Gadekar, D. A. and N. D. Jambhale. 2003 Inheritance of yield and yield components in safflower (Carthamus tinctorius L.). J. of Oilseeds Res. 20: 63-65.

Ghorpade, P. B. and M. R. Wandhare. 2001 Application of simplified triple test cross and combining ability analysis to determine the gene action in safflower. In: Proceedings of the $5^{\text {th }}$ International Safflower Conference, Williston, Sidney, U. S. A. P 79-82.

Golkar, P., A. Arzani and A. M. Rezaei. 2011. Genetic analysis of oil content and fatty acid composition in safflower
(Carthamus tinctorius L.). J. of the American Oil Chemists' Society 88: 975-982.

Golkar, P., A. Arzani and A. Rezaei. 2012. Genetic analysis of agronomic traits in safflower (Carthamus tinctorious L.). Notulae Botanicae Horti Agrobotanici 40: 276-281.

Goncharenko, A. A., S. V. Krakhmalev, S. A. Ermakov, A. V. Makarov and T. V. Semenova. 2013. Diallel analysis of grain quality traits in inbred winter rye lines. Russian Agric. Sci. 39: 13-19.

Griffing, B. 1956. Concept of general and specific combining ability in relation to diallel crossing system. Aust. J. Biol. Sci. 9: 463-493.

Harish Babu, B. N., V. Rudra Naik, L. Hanumantharaya, S. G. Raju and S. D. Yaragoppa. 2005. Evaluation of promising breeding lines of safflower for alternaria tolerance, seed yield and its components. Karnataka J. of Agric. Sci. 18: 803-806.

Huang J., H. Qi, X. Feng, Y. Huang and L. Zhu. 2013. General combining ability of most yield-related traits had a genetic basis different from their corresponding traits per se in a set of maize introgression lines. Genetica 141: 453-461.

Istipliler, D., E. Ilker, F. Aykut Tonk, G. Civi and M. Tosun. 2015. Line $\mathrm{x}$ tester analysis and estimating combining abilities for yield and some yield components in bread wheat. Turkish J. Field Crops 20: 72-77.

Kempthorne, O. 1957. An Introduction to Genetic Statistics. John Wiley \& Sons, New York, USA.

Knowles, P. F. 1958. Safflower. Advances in Agronomy 10: 289-323.

Malik, S. I., H. N. Malik, N. M. Minhas and M. Munir. 2004. General and specific combining ability studies in maize. Int. J. of Agric. and Biology 6: 856-859.

Nai G., J. Singh, S. P. Sharma and C. Lal. 2014. Combining ability analysis in safflower (Carthamus tinctorious L.). Electronic J. of Plant Breed. 5: 208-212.

Narkhede, B. N. and A. M. Patil. 1987. Heterosis and inbreeding depression in safflower. J. Maharashtra Agric. Uni. 12: 337340.

Naserirad, H., A. Soleymanifard, R. Naseri and S. Nasiri. 2013. Study of correlation between important agronomic traits and path analysis for grain and oil yield in safflower. Inter. J. Agronomy and Plant Production 4: 670-673.

Omidi A. H., A. Hassan, H. Khazaei, P. Monneveux and F. Stoddard. 2012. Effect of cultivar and water regime on yield and yield components in safflower (Carthamus tinctorius L.). Turkish J. of Field Crops 17: 10-15.

Ortis L. G., G. Nestares, E. Frutos and N. Machado. 2005. Combining ability analysis of agronomic traits in sunflower (Helianthus annuus L.). Helia. 28: 125-134.

Ozcan, K. and N. Acikgoz. 1999. A statistical analysis program for population genetics. 3. The Symposium of Computer Applications for Agriculture. Cukurova Univ., Adana, Turkey.

Pandya, H. M. and V. D. Patil. 1994. Heterosis in relation to general and specific combining ability in safflower. Gujarat Agril. Uni. Res. J. 20: 75-78.

Pankaj K. N. 2015. Heterosis for Yield and Yield Contributing Characters in Safflower (Carthamus tinctorius L.). M.Sc. thesis. Department of Genetics and Plant Breeding College of Agriculture. India, Raipur.

Patil, P. S., A. M. Patil and A. B. Deokar. 1992. Line x tester analysis for combining ability in safflower. J. of Maharashtra Agric. Univ. 17: 62-64

Patil, S. C. and B. N. Narkhede. 1996. Heterosis for yield and yield components in irrigated safflower. J. Maharashtra Agric. Univ. 21: 261-264. 
Patil, A. J., B. C. Kanade and D. R. Murumkar. 2004. Line x tester analysis for seed yield of safflower. J. Maharashtra Agric. Univ. 29: 336-337.

Patel, B. N. and R. Shrivastava. 2016. Heterosis and inbreeding depression for yield and its components in safflower (Carthamus tinctorius L.). Plant Archives 16: 474-476.

Parameshwarappa, K. G., B. T. Ninganur, V. Rudranaik, G. G. Gulaganji, U. K. Hulihalli and N. K. B. Patil. 1995. Combining ability analysis of seed yield, percent oil and other yield attributes in safflower. J. of Oilseeds Res. 12: 258-261.

Rashid, M., A. A. Cheema and M. Ashraf. 2007. "Line x tester analysis in basmati rice," Pakistan J. of Botany 39: 20352042.

Salgotra, R. K., B. B. Gupta and S. Praveen. 2009. Combining ability studies for yield and yield components in Basmati rice. An Int. J. on Rice 46: 12-16.

Sameer Kumar, C. V., D. Shivani, C. Sreelakshmi and V. Swarnalatha. 2012. Heterosis, inbreeding depression and inheritance of seed yield and its component traits in safflower (Carthamus tinctorius L.). Int. J. of Bio-resource and Stress Management 3: 228-231.

Sarode S. B., P. B. Ghorpade, P. M. Wayazade, S. B. Deshmukh and S. S. Gomashe. 2008. Heterosis and combining analysis in safflower (Carthamus tinctorius Linn.) Asian J. of Bio. Sci. 3: 56-60.

Shivani, D., C. Sreelakshmi and C. V. Sameer Kumar. 2011. Combining ability studies and heterosis for yield and its component traits in safflower (Carthamus tinctorius L.). Electronic J. of Plant Breed. 2: 377- 383.

Shukla S. K. and M. P. Pandey. 2008. Combining ability and heterosis over environments for yield and yield components in two-line hybrids involving thermosensitive genic male sterile lines in rice (Oryza sativa L.). Plant Breed. 127: 2832.

Singh, K. N. and R. Chatrath. 1992. Genetic variability in grain yield and its component characters and their associations under salt stress conditions in tissue culture lines of bread wheat (Triticum aestivum L. em Thell.) Wheat Information Service. 75: 46-53.

Singh,V., M. B. Deshpande and N. Nimbkar. 2001. Potential for commercial exploitation of hybrid vigour for flower yield in safflower and popularisation of safflower flower as herbal health tea. J. Medicinal and Aromatic Plant Sci. 23: 303-307.

Singh, V., N. M. Kolekar and N. Nimbkar. 2008. Breeding strategy for improvement of flower and seed yields in safflower. In: Proceedings of the $7^{\text {th }}$ International Safflower Conference, Wagga Wagga, Australia. http://www.australianoilseeds.com.

Sprague, G. F. and L. A. Tatum. 1942. General vs specific combining ability in single crosses of corn. J. Am. Soc. Agron. 34: 923-952.

Yildirim, M.B. and S. Cakir.1986. Line $\mathrm{x}$ tester analysis. Ege Univ. Computer Res. and Appl. Center J. 9: 11-19. 